\title{
Amelioration of Lead-induced Toxicity in Blood, Liver and Kidney Tissues of Male Wistar Rats by Fermented Ofada Rice
}

\author{
Eferhire Aganbi $^{1 *}$, Oghenetega Jonathan Avwioroko ${ }^{2}$, Emmanuel Rex Enabulele ${ }^{1}$, \\ Joshua Onyeka Osagu ${ }^{1}$, Chinedu Kennis Uwandu ${ }^{1}$, Assumpta Ike ${ }^{1}$, Aaron Akpede ${ }^{1}$, \\ Prince Eferusuoa ${ }^{1}$
}

${ }^{1}$ Department of Biochemistry, Faculty of Science Delta State University Abraka P.M.B 1, Delta State Nigeria. ${ }^{2}$ African Research Laboratories, Otorho-Agbon, Delta State, Nigeria.

\section{A R T I C L E I N F O}

Article history:

Received 17 May 2015

Accepted 20 August 2015

Available online, ISSN: 2148-127X

Keywords.

Ofada rice

Ofada rice koji

Lead-induced toxicity

Total flavonoids

Antioxidants

FRAP assay

${ }^{*}$ Corresponding Author:

E-mail: eaganbi@gmail.com

\section{A B S T R A C T}

The protective effects of 'ofada' rice koji (ORK, fermented ofada rice) and ascorbic acid (AA) against lead $(\mathrm{Pb})$-induced toxicity in the blood, liver and kidney tissues of male Wistar rats was investigated. The animals were divided into four treatment groups (A $\mathrm{D}, \mathrm{n}=5$ ). Groups $\mathrm{B}, \mathrm{C}$ and $\mathrm{D}$ were intoxified by intra-peritoneal injection of $75 \mathrm{mg}$ lead acetate/kg body weight. Groups $\mathrm{C}$ and $\mathrm{D}$ only had their feed mixed with ORK and AA, respectively. The results showed no significant difference in \% packed cell volume (PCV) and $\mathrm{Pb}$ concentrations. Feeding with ORK and AA significantly decreased alanine aminotransferase activities $\left(36.50 \pm 3.54\right.$ and $34.02 \pm 0.05 \mathrm{UL}^{-1}$ respectively) compared to $\mathrm{Pb}$-only treated group $\left(85.50 \pm 3.25 \mathrm{UL}^{-1}\right)$. The ferric reducing antioxidant power (FRAP) for organs increased significantly following intake of feeds mixed with ORK and AA; increases in FRAP was higher for ORK-treated group possibly due to increased total flavonoids concentration following fermentation. Furthermore, $\mathrm{Pb}$-induced high plasma creatinine levels decreased upon treatment with feeds mixed with ORK and ascorbic acid. These findings strongly indicated that feed supplementation with ORK by $45 \%$ may be more effective at ameliorating the effects of $\mathrm{Pb}$-induced toxicity in tissues compared to supplementation with AA by $2 \%$.

\section{Introduction}

Lead $(\mathrm{Pb})$ is among the most common naturally occurring heavy metals known with a wide range of industrial applications; the metal has found use in a variety of anthropogenic processes such as coal and mineral oil combustion, lead-battery manufacturing, paint industries, smelting, mining and alloy processing (Ademuyiwa et al., 2010; Patra et al., 2011). Lead has been described as one of the most toxic metal in the environment (Chatterjee and Rana, 2002; Patra et al., 2011). It also forms part of a group of metals described as carcinogenic to humans and whose carcinogenic potentials is considered to be dependent on metal oxidation state, solubility and complex formation (Koedrith and Seo, 2011). Due to increasing anthropogenic activities and vehicular emissions, studies have indicated that the amount of lead available in the environment for potential consumption via food chains and drinking water supplies is on the rise. As a toxin, lead induces a wide range of physiological, biochemical and behavioral dysfunctions; in particular the kidney, liver, spleen and testes have been identified as key target organs for lead toxicity (Suradkar et al., 2010; Ademuyiwa et al., 2010; Ishiaq et al., 2011; Bandyopadhyay et al., 2014). Previous U.S. blood lead levels (BLLs) of concern for lead exposure were initially set at $10 \mu \mathrm{g} \mathrm{dl}^{-1}$ and $30 \mu \mathrm{gdl}^{-1}$ for children and adults respectively; however blood lead concentrations as low as $5 \mu \mathrm{g} \mathrm{dl}^{-1}$ have been reported to cause adverse health effects in both children and adults (ATSDR, 2007). In general, toxic metals such as lead have been known to increase the production of free radicals such as reactive oxygen species (ROS) and reactive nitrogen species (RNS) in biological systems. This in turn decreases the availability of antioxidant reserves needed to detoxify reactive intermediates leading to oxidative stress and subsequent cell/tissue damage (Ishiaq et al., 2011; Patra et al., 2011; Flora et al, 2012; Ebrahimzadeh-Bideskan et al., 2015). The induction of oxidative stress resulting in damage to key cellular components such as deoxyribonucleic acid (DNA), has been suggested as one of the possible mechanisms of metal-induced carcinogenicity and toxicity (Koedrith and Seo, 2011, Flora et al., 2012; Bandyopadhyay et al., 2014). Several studies have described the ameliorative effects of natural or synthetic antioxidants on metalinduced toxicity. For example, Ishiaq et al. (2011) investigated the effects of the tomato-rich natural antioxidant lycopene as a potent nephro-protective agent in lead induced nephrotoxicity in rats and reported an 
increase in levels of reduced glutathione (GSH) $(5.95 \pm$ 2.1 to $8.2 \pm 0.57 \mu \mathrm{M})$ in experimental groups following tomato supplementation. In another study, the coadministration of lead and vitamin $\mathrm{C}$ (ascorbic acid) to experimental animals resulted in significant elevation of serum activities of aspartate aminotransferase (AST), alanine aminotransferase (ALT) and alkaline phosphatase (ALP) (Suleiman et al., 2013). The increased activity of GSH and elevated levels of the hepatic enzymes is indicative of increased antioxidant activities (in this case lycopene and ascorbic acid); which resulted in the prevention of oxidative cellular damage. Another natural product reported with the potential to ameliorate leadinduced toxicity in hepatic tissues is ginger (Zingiber officinale Roscoe) (Attia et al. 2013). Rice (Oryzae sativa) is a popular cereal consumed by many people around the world, and could be regarded as a staple diet for people in Africa and Asia. The Nigerian-locally produced ofada rice that has been reported as being more nutritious than the popular imported rice (parboiled/polished rice, bagged rice, or also known locally as 'aroso' rice). In terms of nutritional benefits, one study reported higher protein, fat and fiber content in ofada rice compared to parboiled foreign rice (Ebuehi and Oyewole, 2007). Despite strides taken to date in the search for more easily accessible food-derived antioxidants for the control of metal-induced toxicity, no study to date has demonstrated the use of fermented ofada rice (ofada rice koji - ORK) with improved antioxidant properties in the treatment of lead-induced toxicity. In this study, we investigated the efficacy of microbe-fermented ofada rice (ORK) with enhanced antioxidant properties and ascorbic acid as protective agents against leadinduced toxicity in experimental animals.

\section{Materials and methods}

\section{Experimental Animals}

Twenty healthy adult male Wistar rats with weights ranging from 130-220 $\mathrm{g}$ were procured from Akure, Ondo State, Nigeria and used for the experiments. Animals were kept in cages and housed in the animal house unit of African Research Laboratory, Isiokolo, Delta state, Nigeria to acclimatize in their new environment for a period of ten days prior to administration of treatments.

Preparation of fermented ofada rice powder ('ofada rice koji' - ORK)

Ofada rice was purchased from a local market in Ogun State. $800 \mathrm{~g}$ of pebbles/debris-free ofada rice grains was steeped in distilled water $\left(80^{\circ} \mathrm{C}-85^{\circ} \mathrm{C}\right)$ in a large beaker for 1 hour. This was followed by steaming at $121^{\circ} \mathrm{C}$ for $15 \mathrm{~min}$ to sterilize. Freshly prepared suspension of yeast cells (Saccharomyces cerevisae) was introduced as inocula into the sterilized ORK and the culture flask incubated for 15 days at $30^{\circ} \mathrm{C}$. Subsequent procedures as described by Yen et al. (2003) were followed and the resultant fermented ORK was heated to dryness for 10 min using a microwave oven (L.G. Model) set to 'medium-high' Watt calibration icon. This procedure was performed to remove moisture totally from the samples as well as to terminate further microbial activity and fermentation. Dried ORK was later blended into powder form for feed formulation. Following the same procedure above, a separate beaker was prepared for the determination of flavonoid content. After initial introduction of yeast cells, the preparation was stirred and left for 2 hours prior to collection of the first subsample (2 $\mathrm{g}$ of mixture) for day 0 . Further subsamples were collected at day $3,5,7,11$ and 15. Collected subsamples were frozen immediately until required for analysis.

\section{Experimental design}

The twenty male Wistar rats were divided into four groups (A-D) of five rats each $(n=5)$. Group A contained healthy rats (negative control) while rats in Groups B, C and $\mathrm{D}$ were intoxified by intra-peritoneal injection of 75 $\mathrm{mg}$ lead acetate/kg body weight to induce $\mathrm{Pb}$-toxicity. Groups A and B were fed with $100 \%$ normal standard feed diet and served as negative and positive controls, respectively; whereas Groups $\mathrm{C}$ and $\mathrm{D}$ were fed with normal standard feed mixed with fermented Ofada rice (ORK) powder and ascorbic acid (AA), respectively. The feeds fed to animals in Groups $C$ and D contained approximately $55 \mathrm{~g}$ of standard feed mixed with $45 \mathrm{~g}$ of fermented ORK powder $(45 \% \mathrm{w} / \mathrm{w})$ and $98 \mathrm{~g}$ of standard feed mixed with $2 \mathrm{~g}$ of ascorbic acid $(2 \% \mathrm{w} / \mathrm{w})$ by compositions, respectively. Biochemical assays were carried out on the blood, plasma, liver and kidney homogenates of the rats after 15 days of treatment (feeding).

Preparation of ORK extracts and total flavonoid determination

Subsamples of ORK ( $0.5 \mathrm{~g}$ each) collected within the 15-day incubation period were homogenized using methanol $(5 \mathrm{~mL})$ in an ice-cold homogenizer; $2 \mathrm{~mL}$ of distilled water was added to the homogenates in order to stabilize the mixture. The homogenate-methanol mixture was filtered using filter paper (Whatman No. 2) to obtain filtrate with extract, this was collected into labelled test tubes and covered with aluminum foil paper for spectrophotometric analysis. The determination of total flavonoid concentration was carried out using the method described by Jia et al., (1999) with modifications. $250 \mu \mathrm{L}$ of the extract was added to $1.25 \mathrm{~mL}$ of distilled water and $75 \mu \mathrm{L}$ of $5 \% \mathrm{NaNO}_{3}$. After $5 \mathrm{~min}, 150 \mu \mathrm{L}$ of $10 \%$ $\mathrm{AlCl}_{3} \mathrm{H}_{2} \mathrm{O}$ was added, followed by the addition of $500 \mu \mathrm{L}$ of $1 \mathrm{M} \mathrm{NaOH}$ and $275 \mu \mathrm{L}$ of distilled water after $6 \mathrm{~min}$. The final reaction volume was $2.5 \mathrm{~mL}$, solution was properly mixed and absorbance measured against standard at $510 \mathrm{~nm}$ with a spectrophotometer (80-2 Techmel \& Techmel, U.S.A). Standard solution was prepared using $25 \mu \mathrm{L}$ ascorbic acid ( $0.5 \mathrm{~g} / 10 \mathrm{~mL}$ of solution). Flavonoid content was calculated using the relationship:

Total flavonoids $=\mathrm{A}_{\text {sample }} / \mathrm{A}_{\text {standard }} \mathrm{X}$ Concentration of standard

Where $A_{\text {sample }}$ is the absorbance of the sample; $A_{\text {standard }}$ is the absorbance of the standard

Determination of $\mathrm{Pb}$ concentration, ALT activity, $\mathrm{PCV}$ and creatinine levels

The concentrations of lead $(\mathrm{Pb})$ was determined in blood, kidney and liver homogenates using Atomic 
Absorption Spectroscopy (AAS) method as described by Beaty et al. (1993). Plasma alanine aminotransferase (ALT) activity and plasma creatinine level were determined using commercial kits from Randox Laboratories Ltd, UK. Packed cell volume (PCV) was determined using a micro-haematocrit reader (Medisiens Scientific Co. Ltd).

Determination of ferric ion reducing power (FRAP assay)

The ferric ion reducing antioxidant power (FRAP assay) of the samples (plasma, liver and kidney homogenates) was measured spectrophotometrically according to the modified method of Oyaizu (1986). Briefly, $2.5 \mathrm{~mL}$ of $200 \mathrm{mM}$ phosphate buffer (pH 7.0) and $2.5 \mathrm{~mL} 1 \%$ potassium ferricyanide $\left(\mathrm{K}_{3} \mathrm{FeCN}\right)$ were added to $0.5 \mathrm{~mL}$ of sample. Mixture was incubated at $50^{\circ} \mathrm{C}$ for 2 min then centrifuged at $2000 \mathrm{x}$ g for $4 \mathrm{~min} ; 2.5 \mathrm{~mL}$ of the resultant supernatant was mixed with equal volume of distilled water and $0.5 \mathrm{~mL} 0.1 \% \mathrm{FeCl}_{3}$. Absorbance of mixture was measured at a wavelength of $700 \mathrm{~nm}$, catechine $\left(\mathrm{C}_{15} \mathrm{H}_{14} \mathrm{O}_{6}\right)(0.001 \mathrm{~g} / 5 \mathrm{~mL}$; Sigma-Aldrich) was used as a standard antioxidant. The larger the absorbance the higher the reducing power of the sample.

\section{Statistical analysis}

The results were expressed as Mean \pm Standard Deviation. A one-way analysis of variance (ANOVA) was used to analyze data. A P-value $\leq 0.05$ was considered as statistically significant. Where a significant difference was observed, data were further analyzed using Tukey's significant difference (TSD) test to know the groups that caused the significant differences. The analyses were computed using SigmaStat software (version 10).

\section{Results and discussion}

\section{Biochemical analyses}

The protective effects of 'ofada' rice koji (ORK, fermented ofada rice) and ascorbic acid against $\mathrm{Pb}$ induced toxicity in blood, liver and kidney tissues of male Wistar rats was investigated. Mean blood lead concentrations observed among the groups ranged from $60.6 \pm 0.07$ to $69.2 \pm 0.11 \mu \mathrm{g} \mathrm{dL} \mathrm{dL}^{-1}$; there was no significant difference $(\mathrm{P}>0.05)$ between blood lead concentrations for Group A (control) and concentrations for lead-exposed groups. The detected baseline blood lead level $\left(60.6 \pm 0.07 \mu \mathrm{g} \mathrm{dL}^{-1}\right)$ for the negative control group is suggestive of prior exposure to lead possibly via diet. The lack of significant difference between blood lead concentrations for control group and $\mathrm{Pb}$-exposed groups could be as a result of short period of lead intoxication (7 days of intoxication prior to 8 days of treatment of relevant groups with ORK and ascorbic acid respectively). Studies using longer exposure periods have reported significant variations in blood lead levels between control and Pb-exposed groups (Fioresi et al., 2014; Tocchini de Figueiredo et al., 2014). Nevertheless, the highest mean blood lead concentration of $69.2 \pm 0.11$ $\mu \mathrm{g} \mathrm{dL}{ }^{-1}$ was detected for Group B (Pb treated, no ORK and no AA); this amount was slightly reduced on treatment with both ORK and ascorbic acid (see Table 1).
Higher amounts of lead (at least 5 times more) have been found in the bone of experimental animals, even in situations where whole blood lead levels remained unchanged (Tocchini de Figueiredo et al., 2014). Based on their findings, these workers reaffirmed the importance of using bone concentration of $\mathrm{Pb}$ as a more reliable biomarker for exposure rather than whole blood lead concentrations. Similarly, mean lead concentrations in kidney homogenates did not differ significantly $(\mathrm{P}>0.05)$ for the control group (Group A) compared with $\mathrm{Pb}$ exposed groups (Groups B - D) (Table 1). There was a significant increase in lead concentrations in liver homogenates for Group B ( Pb treated only; $69.8 \pm 0.06$ $\left.\mu \mathrm{g} \mathrm{dL}^{-1}\right)$ compared to control group $\left(44.4 \pm 0.09 \mu \mathrm{g} \mathrm{dL}^{-1}\right)$ $(\mathrm{P}<0.05)$. Treatment with ORK resulted in a significant decrease in liver lead concentrations to $48.4 \pm 0.19 \mu \mathrm{g} \mathrm{dL}^{-}$ ${ }^{1}$ while the decrease for ascorbic acid $\left(59.2 \pm 0.08 \mu \mathrm{g} \mathrm{dL}^{-}\right.$ ${ }^{1}$ ) was not significant $(\mathrm{P}>0.05)$.

Table $1 \mathrm{PCV}(\%)$ and concentrations of lead $\left(\mu \mathrm{g} \mathrm{dl}^{-1}\right)$ in blood and organs of rats induced with $\mathrm{Pb}$ toxicity. Values not sharing a common alphabet $(\mathrm{a}-\mathrm{c})$ differed significantly $(\mathrm{P}<0.05)$.

\begin{tabular}{l|cccc}
\hline \multirow{2}{*}{ Treatments } & \multicolumn{4}{|c}{ Lead concentration $\left(\mu \mathrm{g} \mathrm{dl}^{-1}\right)$} \\
\cline { 2 - 4 } & Blood & Kidney & Liver & \\
\hline Group A & $60.6 \pm 0.07^{\mathrm{a}}$ & $42.4 \pm 0.10^{\mathrm{a}}$ & $44.4 \pm 0.09^{\mathrm{a}}$ & $54.0 \pm 4.7^{\mathrm{a}}$ \\
Group B & $69.2 \pm 0.11^{\mathrm{a}}$ & $51.4 \pm 0.08^{\mathrm{a}}$ & $69.8 \pm 0.06^{\mathrm{b}}$ & $42.0 \pm 4.7^{\mathrm{a}}$ \\
Group C & $63.2 \pm 0.03^{\mathrm{a}}$ & $40.0 \pm 0.09^{\mathrm{a}, \mathrm{b}}$ & $48.4 \pm 0.19^{\mathrm{a}, \mathrm{c}}$ & $50.0 \pm 9.42^{\mathrm{a}}$ \\
Group D & $64.0 \pm 0.08^{\mathrm{a}}$ & $51.2 \pm 0.05^{\mathrm{a}, \mathrm{c}}$ & $59.2 \pm 0.08^{\mathrm{b}}$ & $49.5 \pm 7.07^{\mathrm{a}}$ \\
\hline
\end{tabular}

Despite many identified limitations (e.g. influences by non-renal factors such as muscle mass, dietary meat intake, etc. and unreliability), serum creatinine remains the most commonly used marker for measuring glomerular filtration rate (GFR) as an indicator of acute kidney injury (AKI) (Arici, 2014). Estimating GFR based on a filtration marker such as serum creatinine, has become a widely accepted routine clinical practice as an initial test for kidney filtration function or capability (Wu and Parikh, 2008; Arici, 2014). In terms of its use diagnostically, a normal result for creatinine blood test is 0.7 - $1.3 \mathrm{mg} \mathrm{dL}^{-1}$ for men and $0.6-1.1 \mathrm{mg} \mathrm{dL}^{-1}$ for women (MedlinePlus, 2013). However, there is no standardized 'normal' levels of blood (serum/plasma) creatinine for male Wistar rats. Studies have reported values for healthy animals /control group as low as $0.20 \pm$ $0.08 \mathrm{mg} \mathrm{dL}^{-1}$ (Nwangwu et al. 2011) and as high as $10.0 \pm$ $2.3 \mathrm{mg} \mathrm{dL}^{-1}$ (Ishiaq et al. 2011). Detected mean plasma creatinine levels for the groups (Figure 1) showed the trend: Group B $\left(16.94 \pm 3.34 \mathrm{mg} \mathrm{dL}^{-1}\right)>$ Group D (14.65 $\left.\pm 1.10 \mathrm{mg} \mathrm{dL}^{-1}\right)>$ Group C $\left(9.50 \pm 2.86 \mathrm{mg} \mathrm{dL}^{-1}\right)>$ Group A $\left(2.06 \pm 0.34 \mathrm{mg} \mathrm{dL} \mathrm{dL}^{-1}\right)$. There was a significant difference in measured creatinine levels for Group B (Pbonly) when compared to Group A (control group) $(\mathrm{P}<0.05)$. A reduction in creatinine levels was observed on treatment with ORK and ascorbic acid. The difference in plasma creatinine concentration for the two groups (Group B, Pb-only and Group $\mathrm{C}, \mathrm{Pb} / \mathrm{ORK}$ treated) was statistically significant $(\mathrm{P}<0.05)$ while there was no 
significant difference in creatinine levels for Group B when compared with Group $\mathrm{D}$ ( $\mathrm{Pb} / \mathrm{AA}$ treated) $(\mathrm{P}>0.05)$. The results indicated the following: (i) $\mathrm{Pb}$ intoxication resulted in some level of kidney damage as implied by elevated plasma creatinine levels and (ii) by implication of reduced blood creatinine levels, treatment with fermented ofada rice (ORK) was more effective than ascorbic acid (AA) at ameliorating resultant renal dysfunction. Similarly, plasma ALT levels were elevated upon $\mathrm{Pb}$ administration indicating liver damage (Figure 2 ); treatment with both ORK and AA resulted in significant decrease in ALT levels $(\mathrm{P}<0.05)$ (Figure 2).

\section{Determination of total flavonoids concentration}

Flavonoids are one of the most characterized groups of polyphenolic compounds found occurring naturally in plants and plant products. The mechanism of antioxidant action has been the focus of a large number of publications, common mechanisms identified include: their ability to act as free radical scavengers, hydrogen donating compounds, singlet oxygen quenchers, and metal ion chelators (Stefek, 2011). The concentration of total flavonoids in methanol-extracts of fermented ofada rice koji samples was determined from day $0-15$ of the fermentation period. The results showed that flavonoid levels increased significantly $(\mathrm{P}<0.05)$ with increasing fermentation duration, probably as part of fermentationinduced structural changes. By acting on several lignocellulosic materials which form the major structural components of a plant cell, microorganisms release important metabolites including enzymes and bioactive compounds which could be harvested for industrial/commercial purposes. With respect to bioactive compounds, a number of studies have demonstrated the enhancement of antioxidant properties of different agricultural produces and wastes via the use of solid state fermentation (SSF) processes (Martínez-Ávila et al., 2012; Mussatto et al.; 2012). The highest total flavonoid concentration of $76.15 \pm 0.08 \mathrm{mg} \mathrm{mL}^{-1}$ was detected at day 15 , while the lowest concentration was $55.92 \pm 0.06$ $\mathrm{mg} \mathrm{mL}^{-1}$ at day 0 (Table 2).

Antioxidant activities as determined by FRAP assay

The adverse health conditions associated with lead toxicity as revealed by studies is mainly due to its ability to increase the generation of reactive oxygen species (ROS) in different tissues and organs (EbrahimzadehBideskan et al., 2015; Bandyopadhyay et al., 2014; Fioresi et al., 2014). The ferric ion reducing antioxidant power, commonly referred to as the FRAP assay is one of several methods widely employed for the determination of the antioxidant properties of many natural products (Müller et al., 2011; Sudan et al., 2014; Tan et al., 2014).

The antioxidant capacities of plasma, liver and kidney homogenates were evaluated for the four treatment groups (A - D) using FRAP assay. Among the groups, and for the three-sample categories, ORK-treated samples (Group C) showed significantly higher antioxidant activity than $\mathrm{Pb}$-treated and negative control samples (Figure 3).

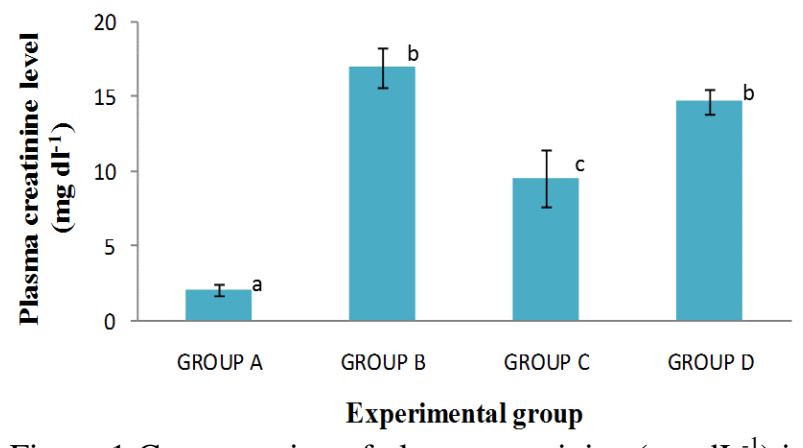

Figure 1 Concentration of plasma creatinine $\left(\mathrm{mg} \mathrm{dL}^{-1}\right)$ in rats induced with $\mathrm{Pb}$ toxicity. Significant increase in Group B compared to Group A indicated by letters b and a, significant decrease in Group C compared to Group B indicated by letters $\mathrm{c}$ and $\mathrm{b}(\mathrm{P}<0.05)$; Values with the same letter did not differ significantly $(\mathrm{P}>0.05)$.

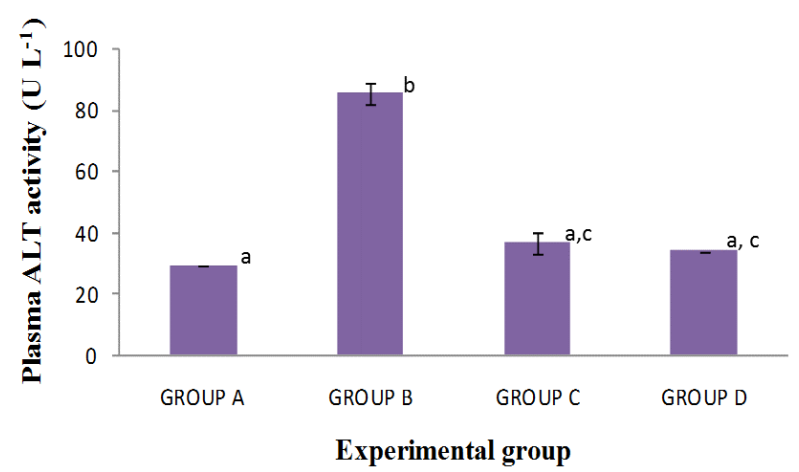

Figure 2. Plasma alanine aminotransferase (ALT) activity $\left(\mathrm{UL}^{-1}\right)$ in rats induced with $\mathrm{Pb}$ toxicity. Significant increase in Group B compared to Group A indicated by letters $\mathrm{b}$ and $\mathrm{a}$, significant decrease in Groups C and D compared to Group B indicated by letters $\mathrm{c}$ and $\mathrm{b}(\mathrm{P}<0.05)$; Values with the same letter did not differ significantly $(\mathrm{P}>0.05)$.

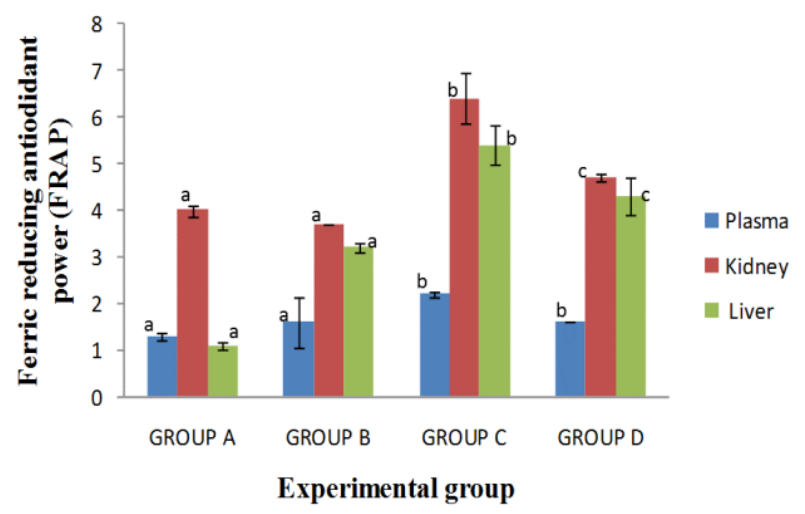

Figure 3. Ferric reducing antioxidant power in plasma, kidney, and liver of rats induced with $\mathrm{Pb}$ toxicity. Antioxidant activity significantly higher for Group C compared to Groups A and B $(\mathrm{P}<0.05)$; Activity also significantly high for Group D compared to Groups A and $\mathrm{B}(\mathrm{P}<0.05)$; Differences in activity for Group $\mathrm{C}$ and $\mathrm{D}$ not significant for plasma but significant for kidney and liver homogenate samples. 
Table 2 Total flavonoids concentration $\left(\mathrm{mg} \mathrm{mL}^{-1}\right)$ in methanol-extracts of fermented ofada rice koji (ORK) over a 15-day fermentation period. Values not sharing a common alphabet $(\mathrm{a}-\mathrm{b})$ differed significantly $(\mathrm{P}<0.05)$.

\begin{tabular}{c|c}
\hline Time (days) & Total flavonoids $\left(\mathrm{mg} \mathrm{mL}^{-1}\right)$ \\
\hline 0 & $55.92 \pm 0.06^{\mathrm{a}}$ \\
3 & $56.10 \pm 0.12^{\mathrm{a}}$ \\
5 & $62.48 \pm 0.08^{\mathrm{a}}$ \\
7 & $64.25 \pm 0.05^{\mathrm{b}}$ \\
11 & $68.95 \pm 0.11^{\mathrm{b}}$ \\
13 & $72.69 \pm 0.09^{\mathrm{b}}$ \\
15 & $76.15 \pm 0.08^{\mathrm{b}}$ \\
\hline
\end{tabular}

The FRAP values displayed by samples in this group followed the trend: kidney > liver > plasma and indicated that the ameliorative effect of ORK was more pronounced in kidney tissues. The ascorbic acid-treated group (Group D) also showed significant ferric reducing power but values were slightly lower than those of Group C (ORKtreated group). Antioxidant studies based on the FRAP assay indicated that fermented ofada rice (ofada rice koji, ORK) has promising ferric ion antioxidant reducing power and may indeed, be more effective than $2 \% \mathrm{w} / \mathrm{w}$ ascorbic acid in combating the stresses of lead-induced toxicity in kidney, liver and blood tissues. The finding that the total flavonoid levels of methanol extracts of ORK increased with the duration of fermentation (Table 2) provides empirical evidence for the observed high antioxidant activity of ORK.

\section{Conclusion}

The results presented revealed that ORK $(45 \% \mathrm{w} / \mathrm{w}$ in animal feed) haboured considerable antioxidant potential possibly surpassing that of $2 \% \mathrm{w} / \mathrm{w}$ ascorbic acid. If this were the case, then the consumption of ofada rice fermented as part of a staple diet has the added advantage of reducing reliance on synthetic drugs with their associated harmful side effects. The results obtained in this work provide a basis for designing future experiments on ofada rice (ORK) for better understanding of its nutritional composition and biological importance; in particular, its antioxidant properties with a focus on characterization of the phytochemicals responsible for these properties. The exact chemical composition of the ORK powder, in terms of active phytochemicals is currently unknown, it would be interesting to conduct further studies to identify and quantify important metabolites /bioactive compounds responsible for the observed antioxidant effects. Nevertheless, the fact that ofada rice is locally produced makes it a ready raw material for obtaining ORK, which according to findings from this study could serve as a cheap and accessible source of natural antioxidants needed to improve the body's defense against oxidative stress and other related diseases.

\section{Acknowledgements}

We are grateful to the management and staff of the African Research Laboratories, Otoroh-Agbon, Delta State, Nigeria for providing experimental animals and laboratory space where work was conducted.

\section{References}

Ademuyiwa O, Agarwal R, Chandra R, Behari JR. 2010. Effects of sub-chronic low-level lead exposure on the homeostasis of copper and zinc in rat tissues. J. Trace Elem. Med. Bio., 24: 207-211.

Arici M. 2014. Clinical Assessment of a Patient with Chronic Kidney Disease. In: Management of Chronic Kidney Disease A Clinicians Guide, Arici M. (Ed.), Springer-Verlag Berlin Heidelberg, pp 15 - 28, DOI 10.1007/978-3-642-54637-2_2.

ATSDR. 2007. Agency for Toxic Substances and Diseases Registry. Toxicological profile for lead. United States Department of Health and Human Services, Atlanta Georgia. Available from:http://www.atsdr.cdc.gov/toxprofiles/tp.asp?id=96\&tid=22 (Accessed on: April 15 ${ }^{\text {th }} 2015$ ).

Attia AM, Ibrahim FA, Nabil GM, Aziz SW. 2013. Antioxidant effects of ginger (Zingiber officinale Roscoe) against lead acetate-induced hepatotoxicity in rats. Afr. J. Pharm. Pharmacol. 7: 1213-1219.

Beaty RD, Kerber JD. 1993. Concepts, instrumentation and techniques in atomic absorption spectrophotometry $\left(2^{\text {nd }}\right.$ Edition). The Perkin-Elmer Cooperation, Norwalk, CT, USA.

Bandyopadhyay D, Ghosh D, Chattopadhyay A, Firdaus SB, Ghosh AK, Paul S, Bhowmik D, Mishra S, Dalui K. 2014. Lead induced oxidative stress: a health issue of global concern. J. Pharm. Res. 8: 1198-1207.

Chatterjee MN, Rana S. 2002 Metabolism of mineral and trace elements. In: Textbook of Medical Biochemistry, $5^{\text {th }}$ ed. Jaypee Brothers Medical Publishers, New Delhi. pp 544 - 545 \& 700 701.

Ebrahimzadeh-Bideskan A, Sadeghi A, Alipour F, Kianmehr M. 2015. The effects of ascorbic acid and garlic on bone mineralization in lead exposed pregnant rats. Zahedan J. Res. Med. Sci., $\mathrm{X}(\mathrm{X})$ : $\mathrm{XX}-\mathrm{XX}$. Available from: http://www.zjrms.ir/files/site1/user_files_10e1c1/kianmehr-A10-2362-1-36fdf99.pdf (Accessed on: Jan 20 2015)

Ebuehi OA, Oyewole AC. 2007. Effect of cooking and soaking on physical characteristics, nutrient composition and sensory evaluation of indigenous and foreign rice varieties in Nigeria. Afr. J. Biotechnol. 6:1016-1020.

Fioresi M, Simoes MR, Furieri LB, Broseghini-Filho GB, Vescovi MV, Stefanon I, Vassallo DV. 2014. Chronic lead exposure increases blood pressure and myocardial contractility in rats. PLoS ONE 9: e96900. DOI:10.1371/journal.pone.0096900.

Flora G, Gupta D, Tiwari A. 2012. Toxicity of lead: a review with recent updates. Interdiscipl. Toxicol. 5: $47-58$.

Ishiaq O, Adeagbo AG, Nta H. 2011. Effect of a natural antioxidant fruit - tomatoes (Lycoperscion esculentium) as a potent nephroprotective agent in lead induced nephrotoxicity in rat. $J$. Pharmacog. Phytother. 3: 63-66.

Jia Z, Tang M, Wu J. 1999. The determination of flavonoid contents in mulberry and their scavenging effects on superoxide radicals. Food Chem., 64: 555 - 559.

Koedrith P, Seo YR. 2011. Advances in Carcinogenic Metal Toxicity and Potential Molecular Markers. Int. J. Mol. Sci., 12: 9576-9595. DOI:10.3390/ijms12129576.

MedlinePlus Medical Encyclopedia. 2013. Creatinine Blood Test Available from: http://www.nlm.nih.gov/medlineplus/ency/ article/003475.htm (Accessed on: Jan 20 2015 and Aug 5 2015)

Martínez-Ávila GC, Aguilera-Carbó AE, Rodríguez-Herrera R, Aguilar CN. 2012. Fungal enhancement of the antioxidant properties of grape waste. Ann Microbiol, 62: 923-930. DOI 10.1007/s13213-011-0329-z.

Müller L, Fröhlich K, Böhm V. 2011. Comparative antioxidant activities of carotenoids measured by ferri antioxidant power (FRAP), ABTS bleaching assay ( $\alpha$ TEAC), DPPH assay and peroxyl radical scavenging assay. Food Chem. 129: 139 - 148. 
Mussatto SI, Ballesteros LF, Martins S, Teixeira JA. 2012. Use of agro-industrial wastes in solid-state fermentation processes. In: Industrial Waste, Prof. Kuan-Yeow Show (Ed.); ISBN: 978953-51-0253-3, InTech. Available from: http://www. intechopen.com/books/industrial-waste/use-of-agro-industrial wastes-in-solid-state-fermentation-processes. (Accessed on Aug $17^{\text {th }} 2015$ )

Nwangwu CO, Josiah S, Abubakar T, Ajeigbe K, Osakue E, Akintola A. 2011. Comparative effects of aqueous and ethanolic leaf extracts of Gongronema latifolium on serum kidney and liver biomarkers of normal male rats. Asian J. Biol. Sci. 4: 540-547.

Oyaizu M. 1986. Studies on products of browning reactions prepared from glucosamine Japanese J. Nutr., 44: 307 - 314.

Patra RC, Rautray AK, Swarup D. 2011. Oxidative stress in lead and cadmium toxicity and its amelioration. Veter. Med. Int., pp 1 - 9. DOI: $10.4061 / 2011 / 45732$.

Stefek M. 2011. Natural flavonoids as potential multifunctional agents in prevention of diabetic cataract. Interdiscipl. Toxicol., 4: $69-77$.

Sudan R, Bhagat M, Gupta S, Singh J, Koul A. 2014. Iron (FeII) chelation, ferric reducing antioxidant power, and immune modulating potential of Arisaema jacquemontii (Himalayan Cobra Lily). BioMed Res. Int., pp $1-7$. http://dx.doi.org/10.1155/2014/179865.
Suleiman JB, Eze ED, Momoh IJ, Usman W, Hedima NC, Zipele HM, Isa A. 2013. Ameliorative Effect of Vitamin C on serum liver enzymes in lead-induced toxicity in Wistar rats. J. Sci., 3: $188-192$.

Suradkar SG, Vihol PD, Patel JH, Ghodasara DJ, Joshi BP, Prajapati KS. 2010. Patho-morphological changes in tissues of Wistar rats by exposure of lead acetate. Veter. World, 3: 82-84.

Tan C, Xue J, Abbas S, Feng B, Zhang X, Xia S. 2014. Liposome as a delivery system for carotenoids: Comparative antioxidant activity of carotenoids as measured by ferric reducing antioxidant power, DPPH assay and lipid peroxidation. J. Agri. Food Chem. 62: 6726-6735.

Tocchini de Figueiredo FA, Gerlach RF, Silva da Veiga MA, Nakadi FV, Ramos J, Kawakita EK, Guerra C, Issa JM. 2014. Reduced bone and body mass in young male rats exposed to lead. BioMed Res. Int., pp 1-5. http://dx.doi.org/10.1155/2014/571065.

Wu I, Parikh CR. 2008. Screening for kidney diseases: older measures versus novel biomarkers. Clin. J. Ameri. Soc. Nephrol. 3: 1895-1901.

Yen G, Chang Y, Su S. 2003. Antioxidant activity and active compounds of rice koji fermented with Aspergillus candidus. Food Chem. 83: 49-54. 